organizations made in $1956-58$ by Dr. D. J. Campbell are analysed in a report by $\mathrm{Mr}$. C. W. Hanson, now published by the Association of Special Libraries and Information Burcaux (Pp. vi $+42+v i$. London: Aslib, 1960. 12s. 6d.; ヘslib members 10s.). 'The survey was undertaken to provide factual data on the size, scope, organization, methods and cost of such units in the United Kingdom and it is based on a 12 per cent sample. Two-thirds of the units surveyod were responsible to a head of research or to a director, the remainder mostly to a senior technical officer. In terms of employees or staff the smaller organizations had relatively larger units than the larger organizations; the number of people served per information/library worker averaged 54, ranging from less than 20 to 200 . 58 per cent of the heads of units wore either graduates or chartered librarians or both. There were more men than women heads, but more of the women were qualified, and among the supporting staff there were three women to one man. Salaries and wages of staff accounted for about three times as much as the purchase of documents. Accommodation averaged 200 sq. $\mathrm{ft}$. per member of information/library staff, but two-thirds of the organizations outside of London exceeded this figure. Two-thirds of the organizations took between 100 and 300 periodicals, the median number being 210 , and one in twelve was in a foreign language; 16 per cent were later bound and 25 per cent were kept indefinitely unbound. Data on books were insufficient to permit any deductions, and only 6 out of the 52 units were responsible for the present organization's technical correspondence files. About half the units scanned national or local newspapers ; 37 per cent possessed a microfilm reader and 8 per cent a microcard reader. About half used the Universal Decimal Classification, the rest using their own schemes. The main catalogue of 35 units comprised a classified index on cards; only one used a punched card subject index. Documonts borrowed from outside libraries for 27 of the units averaged 12 per cent of the number lent from their own stock. About half did little or no stocktaking, and 48 units employed 23 different methods for recording loans. Only one-third could report how many inquiries they handled, but 90 per cent issued some kind of serial publication, commonly lists of new books and selected literature references, with abstracts.

\section{Kirkia : a New Herbarium Journal}

THE aim of Kirkia, the new journal of the Federal Herbarium, Salisbury, Rhodesia and Nyasalund (editor, H. Wild. From the Government Printer, P.O. Box 8062, Causeway, Salisbury. \&l 10s. per annum), is to provide botanists in these rogions, and elsewhere, with a readily available source of taxonomic information on a floristic region of very considerable interest; and to afford a modium for relevant botanical publications. To quote: "With regard to the aims of the journal our intention is to confine ourselves to articles concerning African botany and to give priority to articlos dealing with taxonomy, floristic studies, phytogeography and the history of botany and botanical exploration which have some bearing on the flora of the Federation. Ecological articles may bo published but usually only if they are of a general nature. As space permits we will weleome articles on these subjects relating to other African territories and particularly those territories which are our noar neighbours". The name chosen for the new journal commemorates the work of Sir John Kirk (1832-1922), who, as botanist, accompanied Livingstono to the Zambesi, Victoria Falls, Lake Nyasa, etc.

\section{Museum of Comparative Zoology, Harvard}

THE annual report for 1957-58 of the Director of the Museurn of Comparative Zoology at Harvard College records progress in its usual activities of rescarch, instruction to graduate students and curatorial routine (Pp. 28. Cambridge, Mass. : Museum of Comparative Zoology at Harvard College, 1960). The year was also marked by rather unusual activities such as expeditions by members of the staff to Asia, Australia and South America. Especially noteworthy of mention was a substantiel grent from the National Science Foundation for the improvement of the collections and other facilities. The grant is to be spent over a fivo-yoar period and much of it will be used on scientific and technical assistance to bring the collections into good shepe. Microscopes, other types of equipment and badly needed storage cases were also purchased. The report concludes with an impressive list of publications.

\section{The National Museums of Southern Rhodesia}

THE chief item of interest in the annual report for 1959 of the three museums which comprise the National Museums of Southern Rhodesia is an account of the handing over of the Umtali Museum. This was previously owned by the Umtali Museum Society, but is now administered by the Trustees of the National Museums of Southern Rhodesia. The Municipality of Umtali has allocated a one-acre site to house the material collected by the Society and also made a generous grant. The staff has been reorganized so that the Director of the Museums is now relieved of detailed administration of any one Museum and can devote his energies to overall planning.

\section{New Electronic Teaching Apparatus}

THE (Kriffin-ClarkeSmith elcctronic teaching apparatus 'Mechtronics' is a set of apparatus designed for easy assembly by pupils. A minimum amount of manual and technical skill is demanded of the user, since soldered joints are eliminated and the assemblies are screwed or clipped together on a peg-board layout. The complete set contains radio valves, transistors, a photoclectric device, and other electrical components. For qualitative experiments batteries only are required. For quantitative experiments external instruments are required together with suitable power supplies. 'The 'Mechtronics' set covers the require. ments of the revised syllabus for the General Certificate of Education at Ordinary and Advanced Levels, and may be used by the enthusiast for a wide range? of other electronics experiments. The apparatus is obtainable from Griffin and George, Ltd., Ealing Road, Alperton, Middlesex.

\section{American Palms lllustrated}

TrF Chicago Field Museum of Natural History, which has issued many admirable volumes on the florn of Central and South America, including B. E. Dahlgren's "Index of American Palms" (14, Bot. Ser., pp. 438 ; 1936), has now produced a companion volume of palm illustrations (Dahlgren, B. E., 14, 412 plates; 1959.10 dollars). Theso consist of 